\title{
The Research on Influence Factors of the Servitization of the Equipment Manufacturing Industry under the Global Value Chain (GVC) Perspective
}

\author{
Xiaowei $\mathrm{Xu}^{*}{ }^{\mathrm{a}}$ Xueyuan Wang ${ }^{\mathrm{b}}$ and Rui Zhang ${ }^{\mathrm{c}}$ \\ School of management, Harbin University of science and technology, Harbin, \\ 150080, China \\ a4994129@qq.com, ${ }^{b}$ wangxueyuan@hrbust.edu.cn, ${ }^{c} 4502921 @ 163 . c o m$
}

\begin{abstract}
The servitization of the equipment manufacturing industry is an important way for equipment manufacturing industry to adapt to the new competitive environment, and achieve industrial upgrading based on service function strengthening on value added stages along value chain. In this paper, the necessity of the servitization of the equipment manufacturing industry are analyzed in detail, and quantitative measure are used to analyze the key factors affecting servitization of the equipment manufacturing industry from external and internal two aspects. According to the influence factor analyzing results, specific methods of servitization are put forward.
\end{abstract}

Keywords: equipment manufacturing industry, servitization, motivation, influences factors

\section{Introduction}

The equipment manufacturing industry is the production and manufacturing department providing technical equipment for reproduction/expanding reproduction of the industries of national economy, which is the core part of the manufacturing industry. The equipment manufacturing industry is a strategic industry in China [1]. It provides the necessary technical equipment and important parts for production of all industries, and makes production elements gather to the department with high technology and profits by technology innovation, which can reduce the production cost and promote the technology innovation progress in other industries greatly. Equipment manufacturing industry in China is big but not strong at present, it is also in the low-end of value chain [2]. Therefore, making more skills and knowledge embed into equipment products through the servitization to raise position in value chain has become inevitable. Then it becomes a key problem to analyze motivation and influence factors of the servitization of the equipment manufacturing industry, and to find specific way of servitization management according to analysis results of influence factors.

\section{The Necessity of Servitization of the Equipment Manufacturing Industry}

New industry technology revolution taking information technology as typical example is reconstructing the new pattern of global economic and social development. Technology innovation is accelerating, and the international competition of enterprises is intensifying, globalization is continuously deepening, adjustment of industrial structure is accelerating, and the global equipment manufacturing industry is facing a new development environment. Foreign enterprises investing to China accelerates the development of two ends off-shore model of equipment manufacturing industry, which prevents the extension in global 
value chain for domestic industry, and weakens the driving effects to domestic enterprises [3]. Then the status of equipment manufacturing industry in the global value chain is presented by measuring the development level of industry inner trade in China, which proves the necessity of improving equipment manufacturing industry servitization to enhance its competition in global value chain.

\subsection{Development Level Estimation Method}

2.1.1. The Total Intra-industry Trade Index: The total intra-industry trade index is to measure the level of intra-industry trade; it presents the degree of import and exports of similar products within the same industry in trading nations [4]. The raising of intra-industry trade is benefit to the country's further development of economic \& trade and technological progress. GL index method is put forward by Grubel. H. G and Llovd. P. J which is now widely recognized [5], the calculation formula is:

$$
G L_{i}=1-\frac{\left|X_{i}-M_{i}\right|}{\left(X_{i}+M_{i}\right)}
$$

$G L_{i}$ is the industry trade index within the industry, and $X_{i}$ and $M_{i}$ are the exports and imports of the $i^{\text {th }}$ product group. $G L$ is in the interval $[0,1]$. When $X_{i}=M_{i}, G L_{i}=1$, that is to say, all trade is intra-industry trade. If $X_{i}=0$ or $M_{i}=0$, then $G L_{i}=0$, that indicates all trade is inter-industry trade. The value of $G L_{i}$ is more close to 1 , the higher degree of intra-industry trade, the value of $G L_{i}$ is more close to 0 , the lower level of intra-industry trade.

When measuring comprehensive intra-industry trade level of multiple product groups, the total weighted formula is:

$$
\sum W_{i} G L_{i}=\frac{\left(X_{i}+M_{i}\right)}{(X+M)}-\frac{\left(X_{i}+M_{i}\right)}{(X+M)} \bullet \frac{\left|X_{i}-M_{i}\right|}{\left(X_{i}+M_{i}\right)}
$$

Among them, $G L_{i}$ represents GL index of each subclass product within a period of time, $W_{i}$ represents the weight of the $\mathrm{i}^{\text {th }}$ subclass product in the categories of products, which can be got by $\left(X_{i}+M_{i}\right) /(X+M)$. When the value of the total intra-industry trade index $\sum W_{i} G L{ }_{i}$ is above 0.5 , the intra-industry trade of the product is predominant. On the contrary, the inter-industry trade is predominant.

2.2.2. Horizontal Intra-industry Trade and Vertical Intra-industry Trade: Intraindustry trade is divided into horizontal intra-industry trade and vertical intra-industry trade [6]. Import and export of differentiation product with the same or similar quality but different performance and properties is called horizontal intra-industry trade; import and export of different products with the different quality is called vertical intra-industry trade [7]. According to Greenaway \& Milnor's standard:

$R U V_{X M}=U V_{w t, l, y}^{X} / U V_{w t, l y}^{M}$, among them $U V_{w t, l, y}^{X}$ and $U V_{w t, l y}^{M}$ respectively represents export price of the $t$ market and imports price from t market of the ith product in the yth year in the wth country.

The division standard of horizontal intra-industry trade is:

$$
1-\beta \leq R U V_{X M} \leq 1+\beta
$$

The division standard of vertical intra-industry trade is:

$$
R U V_{X M} \geq 1+\beta \text { or } R U V_{X M} \prec 1-\beta
$$

Among them, $\beta=0.25$. $R U V_{X M} \succ 1+\beta$ represents upward vertical intraindustry trade. This shows that it is in the high-end position in industrial division, 
$R U V_{X M} \prec 1-\beta$ represents downward vertical intra-industry trade, this shows that it is in the low-end position in industrial division.

\subsection{The Estimation of the development level of industry inner trade of equipment manufacturing industry}

Because industry standard of HS4 digit grouping can reflect industrial and national characteristics, therefore, HS4 digit product grouping criteria is applied in this paper [8]. The intra-industry trade index and the structure of intra-industry trade of different segments of equipment manufacturing industry in China are calculated according to the data from UN UNCOMTRADE database.

It can be seen from table 1, the level of intra-industry trade of general equipment manufacturing, electric machinery and equipment manufacturing and transportation equipment manufacturing becomes higher from 2000 to 2007, and the overall trend of intra-industry trade of special equipment manufacturing, instruments and meters, and culture, office machinery manufacturing is also increasing despite some fluctuations. Only intra-industry trade of the communication and electronic equipment manufacturing has fallen since 2000, and the index of industry inner trade is less than 0.5 since 2002 . This shows that the intra-industry trade is small, it is mainly inter-industry trade. In general, the investment behaviors of multinational companies can greatly promote the development of intra-industry trade with the increasing of direct investment on Chinese equipment manufacturing industry.

Table 1. The Total Intra-industry Trade Index of Equipment Manufacturing Industry in China

\begin{tabular}{lllllllll}
\hline industry & 2000 & 2001 & 2002 & 2003 & 2004 & 2005 & 2006 & 2007 \\
General equipment & 0.61 & 0.61 & 0.63 & 0.60 & 0.60 & 0.66 & 0.67 & 0.68 \\
$\quad$ Special equipment & 0.35 & 0.32 & 0.33 & 0.35 & 0.39 & 0.51 & 0.56 & 0.58 \\
Electrical machinery & 0.61 & 0.59 & 0.58 & 0.58 & 0.58 & 0.59 & 0.60 & 0.59 \\
Communication electronics & 0.54 & 0.50 & 0.49 & 0.41 & 0.43 & 0.42 & 0.41 & 0.39 \\
Instrument and meter & 0.48 & 0.50 & 0.44 & 0.39 & 0.47 & 0.52 & 0.52 & 0.58 \\
\hline
\end{tabular}

Products export/import unit value $=$ export price/import price. The result of export/import unit value of industry products is shown in figure 1 using UNCOMTRADE data according to the above formula.

According to the data, the proportion of horizontal intra-industry trade of the Chinese equipment manufacturing industry has widened. But in general, the unit value of import and export of the rest of subdivision industry are less than 0.75 except the communication and electronic equipment manufacturing industry which is mainly horizontal intraindustry trade. Therefore, the down vertical industry trade is also the main industry of each segment of equipment manufacturing industry in China. Despite the import and export trade of Chinese equipment manufacturing industry rapid growth, there is no promotion in global value chain accordingly, therefore servitization of manufacturing industry should be applied to change current situation. 


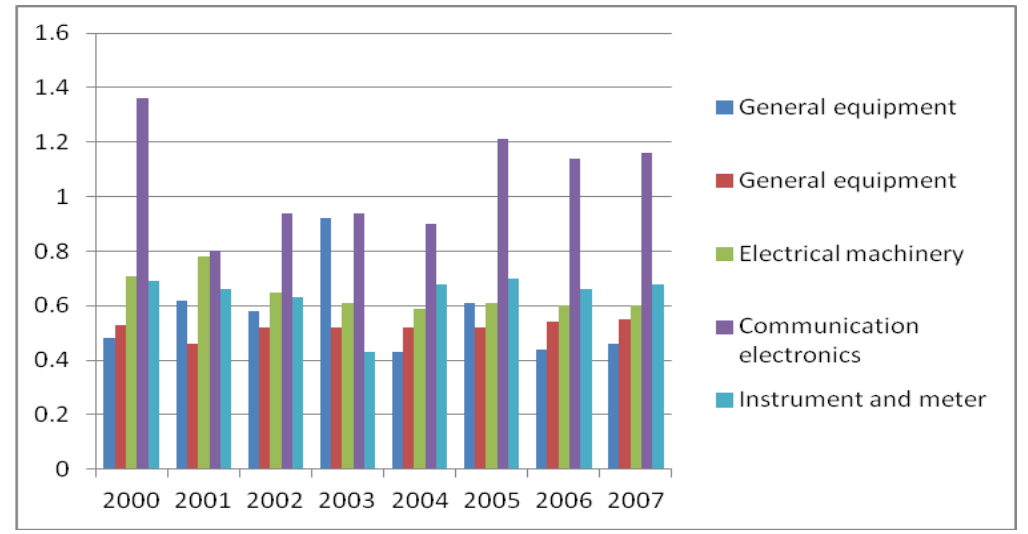

Figure 1. Unit Value of Products Export/Import of Various Industries

\section{Influencing Factors Measurement on the Servitization of Equipment Manufacturing Industry}

\subsection{The Measure Index of Influencing Factors}

The choice of influence factors index on the servitization of equipment manufacturing industry is based on influence factors analysis. It mainly includes resource constraints, the strength of industry competition, service economy level, technical progress factor, government policy and system, the attention on service of top managers, the quality of staff and specialization of the organization. Among them, the resource constraints can be reflected by energy consumption of per unit output of the equipment manufacturing industry. The greater the index is, the resource constraint is more obvious ${ }^{[9]}$. As the principles show that the competitive market is less radical when industrial concentration is higher, so concentration index is used to measure industry competition strength. Regional tertiary industry share of GDP is used to measure service economy. The new product development project and informatization index are used to measure technical progress factor. Government policy and system is weighted by the index of proportion of government funds (GF) for EMI investment. Top manager's emphasis on service can be reflected by the index of the proportion of sales revenue funds for $R \& D$ and marketing investment. Number of employees and structure use EMI on-the-job worker number and the ratio of employees with college degree or above to measure. Specialization of the organization adopts the number of productive service enterprise in various areas as index.

Table 2. The Index System of Influence Factors of the Servitization of the Equipment Manufacturing Industry

\begin{tabular}{llc}
\hline \multicolumn{1}{c}{ The main index } & \multicolumn{1}{c}{ Measure index } & effect \\
\hline $\mathrm{I}_{1}:$ Resource constraints & $\mathrm{I}_{11}:$ Energy consumption of per unit output for EMI & + \\
\hline $\mathrm{I}_{2}:$ The intensity of industry competition & $\mathrm{I}_{21}:$ Industrial concentration index & - \\
\hline $\mathrm{I}_{3}:$ The level of service economy & $\mathrm{I}_{31}:$ The proportion of the tertiary industry to GDP & + \\
\hline $\mathrm{I}_{4}:$ Technical progress factor & $\mathrm{I}_{41}:$ The number of new product development & + \\
\hline $\mathrm{I}_{5}:$ The policy \& system of government & $\mathrm{I}_{42}:$ : the proportion of EMI investment in GF & + \\
\hline $\mathrm{I}_{6}:$ management level of Senior managers $\mathrm{I}_{61}:$ total asset turnover of EMI & + \\
\hline $\mathrm{I}_{7}:$ The number and structure of & $\mathrm{I}_{71}:$ employees share of College degree or above & + \\
employees & $\mathrm{I}_{72}:$ EMI on-the-job worker number & + \\
\hline $\mathrm{I}_{8}:$ Specialization of the organization & $\mathrm{I}_{81}:$ Number of regional productive service & enterprise \\
\hline
\end{tabular}




\subsection{The Data Source and the Evaluation Model}

1. The input-output method is used in this paper. Calculation of the servitization level of the equipment manufacturing industry is shown as the following:

$$
d_{i j}=\frac{a_{i j}}{\sum_{i=1}^{n} a_{i j}}
$$

Among them, $a_{i j}$ is the input coefficient of all intermediate products of one industry, which is the direct consumption coefficient. It can be calculated by following formula:

$$
a_{i j}=\frac{\sum_{i}^{n} x_{i j}}{\sum_{i}^{n} x_{i j}+D_{j}+N_{j}}
$$

Merged by seven industries of equipment manufacturing industry, a new input and output data are formed, and the calculation of input coefficient is based on these data, that is to say direct consumption coefficient. Calculate dependence can be obtained based on direct consumption coefficient. The results are shown in Table 3 .

Table 3. The Direct Consumption Coefficients of Input and Output of All kinds Service of the Equipment Manufacturing Industry in China

\begin{tabular}{cccccc}
\hline Input & $\begin{array}{c}\text { Transport and } \\
\text { the postal } \\
\text { service }\end{array}$ & $\begin{array}{c}\text { Commercial } \\
\text { catering }\end{array}$ & $\begin{array}{c}\text { Public utilities } \\
\text { and the residents } \\
\text { service }\end{array}$ & $\begin{array}{c}\text { The financial } \\
\text { insurance } \\
\text { industry }\end{array}$ & $\begin{array}{c}\text { Other } \\
\text { industries }\end{array}$ \\
\hline 1997 & 0.018 & 0.074 & 0.006 & 0.013 & 0.004 \\
\hline 2000 & 0.019 & 0.037 & 0.012 & 0.011 & 0.004 \\
\hline 2002 & 0.019 & 0.034 & 0.012 & 0.010 & 0.003 \\
\hline 2005 & 0.026 & 0.045 & 0.027 & 0.012 & 0.008 \\
\hline 2007 & 0.040 & 0.040 & 0.021 & 0.010 & 0.011 \\
\hline
\end{tabular}

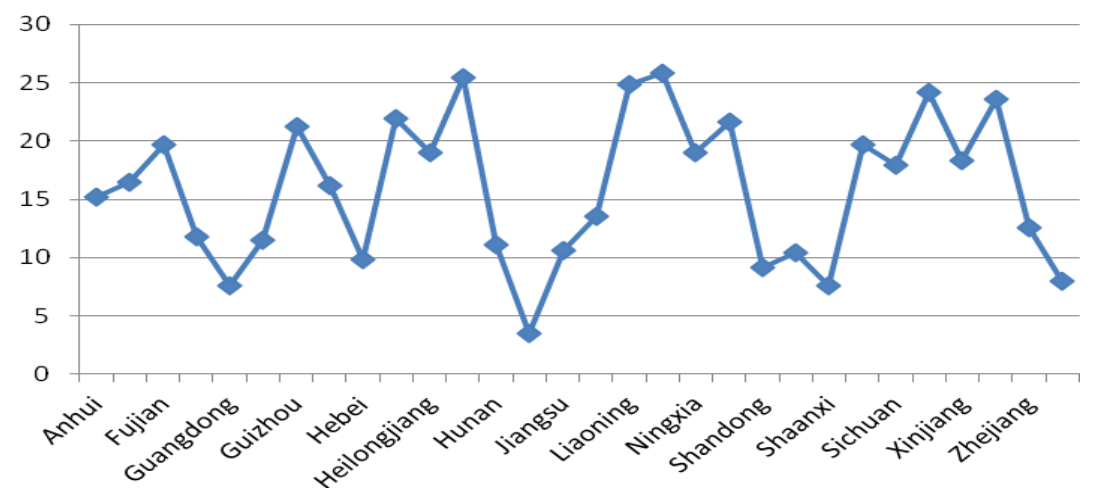

\section{Figure 2. The Degree of Dependence to Service Industry of the Equipment Manufacturing Industry}

Data show that productive service inputs are relatively small in each segment of equipment manufacturing industry in China. The producer service industry development is lags off. Using modified forms of Cobb-Douglas production function, we expand independent variables from capital and labor to the sources of energy, services to examine the influence factors of service by estimating the production function. Then the theoretical model of servitization evaluation on the equipment manufacturing industry in China is built, which can be seen as follows: 


$$
\begin{aligned}
& \lg \left(S L_{i}\right)=\beta_{0}+\beta_{1} \lg S C_{i}+\beta_{2} \lg \operatorname{copm}_{i}+\beta_{3} \lg \operatorname{ser}_{i}+\beta_{4} \lg T P_{i}+\beta_{5} I T_{i}+\beta_{6} \lg G I_{i} \\
& +\beta_{7} \lg T M L_{i}+\beta_{8} \lg E E L_{i}+\beta_{9} \lg E N_{i}+\beta_{10} \lg M S N_{i}+\delta
\end{aligned}
$$

Among them $\lg \left(S L_{i}\right)$ means the servitization level of equipment manufacturing industry in the $\mathrm{i}^{\text {th }}$ region, from $S C_{i}$ to $M S N_{i}$ represent influencing factors on servitization, and from $\beta_{0} \beta_{10}$ are used to reflect related constants or coefficient, and $\delta$ is the random error, the results can be seen in Table 4 .

Table 4. Coefficients of the Model

\begin{tabular}{lccccc}
\hline \multicolumn{1}{c}{ Model } & \multicolumn{2}{c}{$\begin{array}{c}\text { Unstandardized } \\
\text { Coefficients }\end{array}$} & $\begin{array}{c}\text { Standardized } \\
\text { Coefficients }\end{array}$ & t & Sig. \\
& B & Std. Error & Beta & & \\
\hline \multicolumn{1}{c}{ Constant) } & 28.43 & 11.23 & & 1.62 & 0.12 \\
\hline Energy consumption of per unit output & 4.73 & 3.52 & .58 & 1.58 & 0.08 \\
\hline Industrial concentration & -23.11 & 4.25 & -.39 & -5.89 & .008 \\
\hline The proportion of the tertiary industry to GDP & 26.46 & 12.35 & .44 & 2.67 & .039 \\
\hline The number of new product development & 86.55 & 39.12 & 1.13 & 2.91 & .008 \\
\hline Regional informatization index & 21.69 & 17.04 & .52 & 1.96 & .046 \\
\hline the proportion of EMI investment in GF & -6.50 & 5.89 & -.26 & -1.03 & .29 \\
\hline total asset turnover of EMI & 28.76 & 36.31 & .11 & 2.35 & .049 \\
\hline $\begin{array}{l}\text { employees share of college degree or above } \\
\text { EMI on-the-job worker number }\end{array}$ & 22.4 & 3.72 & .13 & 1.2 & .094 \\
\hline $\begin{array}{l}\text { Number of regional productive } \\
\text { enterprise }\end{array}$ & .812 & 22.365 & .061 & .538 & .58 \\
\hline
\end{tabular}

Based on the results, it can be seen that these factors such as industry competition strength, technical progress factor, the development of service economy, the level of management of resource constraints, senior managers, employees and specialization degree of organizational are related to the servitization of equipment manufacturing industry with significant positive relation, while government policy and system have a negative impact. These factors can be summed up to inner organization and external environment factors.

\section{Analysis and Application of the Results of Servitization Influence Factor}

\subsection{The Analysis and Application of the Results of Internal Factors}

Internal organization factors including internal management level, staff structure, knowledge application. Therefore, it put forward higher requirements to the enterprise human resources management and enterprise culture construction. Enterprises should develop strategy for the future of human resources development. It includes stable talent team, improving staff quality, increasing the content of talents, optimizing the structure of human resources, strengthening the vitality of employees. Let the concept of service root and spread. Emphasize the relationship coordination, take meeting customer demand as the goal, make human resource management planning with the concept of "service 
oriented". In addition, business leaders should enhance the service consciousness, and set an example for employees.

\subsection{The Analysis and Application of the Results of External Factors}

The external environment factors including the intensity of industry competition, service economy level, technical progress factor and government policy and system. Develop public service platform, which can provide industrial design, e-commerce and information services; and integrate information technology into producing stages, such as product research and development design, production, operation and management and so on. Develop the digital manufacture, artificial intelligence, industrial robots, improve the agility and flexibility of manufacturing, optimize mass customization production, improve product quality and digital and intelligent level. At the same time, develop system integration and remote monitoring on the basis of information technology.

\section{Conclusion}

The qualitative and quantitative method are combined in this paper to find out the influence factors of the servitization of the equipment manufacturing industry by analyzing Chinese equipment manufacturing industry status in global value chain and the motivation of service are also analyzed by calculating the servitization of equipment manufacturing industry, the following conclusions and suggestions can be obtained based on the theoretical analysis and empirical research:

1. The equipment manufacturing industry in China is still at the low-end position in the global value chain, the rapid growth of import and export trade not promotes the position in global value chain, and the down vertical intra-industry trade is more predominant currently.

2. The servitization of the equipment manufacturing industry is an important support for value chain upgrading. Motivation of the servitization of the equipment manufacturing industry is mainly influenced by the external environment and internal organization factors. External environmental factors include industry competition strength, technical progress factor, and service economy development, resource constraints, which have significant role in promoting the servitization, while government policy and system have a negative impact. Internal organizational factors, such as the management level of highlevel managers, employees and the organization degree of specialization, affect significantly.

\section{ACKNOWLEDGEMENTS}

This work has been supported by the research projects National Nature Science Foundation of China 71403070 and in part by the Seventh Framework Program of the European Union PIRSES-GA-2011-295130.

\section{References}

[1] T. S. Baines, H. Lightfoot, O. Benedettini, O., et al., "The adoption of servitization strategies by UKbased manufacturers", Proceedings of The Institution of Mechanical Engineers Part B-Journal of Engineering Manufacture, vol. 224, no. B5, pp. 815-829.

[2] A. Jergovic, A. Vucelja, B. Inic, et al., "Transformation of business entities-from production to service company", Technics Technologies Education Management, 6, no. 1, (2011), pp. 118-129.

[3] L. Aija, "The benefits of R\&D and breadth in innovation strategies: a comparison of Finnish service and manufacturing firms", Industrial and Corporate Change, vol. 21, no. 5, (2012), pp. 1255-1281.

[4] S. S. Li, C. Hao and E. G. Pleggenkuhle-Miles, "Moving upward in global value chains the innovations of mobile phone developers in China, Chinese Management Studies, vol. 4, no. 4, (2010), pp. 305-321. 
[5] L. Jiguo, "The research on development trend of the servitization of the equipment manufacturing industry", Economic science press, (2008), pp. 121-127.

[6] X. Tang and S. Tang, "The empirical study of equipment manufacturing industry and economic growth in China", Chinese industrial economy, vol. 12, (2011), pp. 27-36.

[7] Z. He and L. Sun, "The servitization of manufacturing industry in China: theory, path and its social influence", Tsinghai university press, Beijing, (2012).

[8] A. Macpherson, "Producer Service Linkages and Industrial Innovation: Results of a Twelve-year Tracking Study of New York State Manufacturers", Growth and Change, vol. 39, no. 1, (2008), pp. 1-23.

[9] G. Heiko, R. Guang-Jie, V. Aku, et al., "Service-driven manufacturing Provision, evolution and financial impact of services in industrial firms", Journal of Service Management, vol. 23, no. 1, (2012), pp. 120-136. 